\title{
Association of the 894G $>$ T polymorphism of the endothelial constitutive nitric oxide synthase gene with unstable angina
}

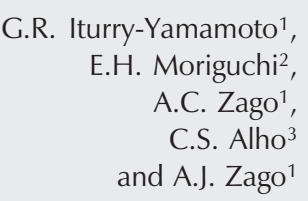

\author{
${ }^{1}$ Unidade de Hemodinâmica, Hospital de Clínicas de Porto Alegre, \\ ${ }^{2}$ Curso de Pós-Graduação em Medicina, Cardiologia, \\ Universidade Federal do Rio Grande do Sul, Porto Alegre, RS, Brasil \\ ${ }^{3}$ Laboratório de Genética e Biologia Molecular, Faculdade de Biociências, \\ Pontifícia Universidade Católica do Rio Grande do Sul, Porto Alegre, RS, Brasil
}

\author{
Correspondence \\ G.R. Iturry-Yamamoto \\ Unidade de Hemodinâmica \\ Serviço de Cardiologia \\ Hospital de Clínicas de Porto Alegre \\ Rua Ramiro Barcelos, 2350, Sala 2059 \\ 90035-003 Porto Alegre, RS \\ Brasil \\ Fax: +55-51-3330-5281 \\ E-mail: iturryamamoto@yahoo.com \\ Research supported by FAPERGS (No. \\ 01/0075.6) and Fundo de Incentivo \\ à Pesquisa do Hospital de Clínicas \\ de Porto Alegre (No. 00-246). \\ G.R. Iturry-Yamamoto was the \\ recipient of postdoctoral \\ fellowships from FAPERGS \\ (No. 00/60014.3) and CNPq \\ (No. 150102/01-1(NV)).
}

Received October 26, 2005 Accepted October 9, 2006

\begin{abstract}
The $894 \mathrm{G}>\mathrm{T}$ polymorphism of the endothelial constitutive nitric oxide synthase gene consists of the substitution of a guanine base by a thymine at the 894th nucleotide of the gene. An association of this polymorphism with acute coronary syndromes has been described, only when in combination with other polymorphisms of this gene. The aim of the present study was to search for an association between this polymorphism and unstable angina in a southern Brazilian population. In a case-control study, 156 patients (group $1(\mathrm{~N}=83)$ : unstable angina, group $2(\mathrm{~N}=73)$ : stable angina) were genotyped by PCR and digestion of the product. Univariate analysis demonstrated that the minimal luminal diameter and the degree of stenosis of the culprit lesion differed between groups ( $\mathrm{P}=0.006$ and 0.005 , respectively). In addition, the frequencies of the $\mathrm{T}$ allele and of the $\mathrm{T}$ allele carriers (combined TT and TG genotypes) were significantly higher in the group with unstable angina (41.6 vs $28.8 \% ; \mathrm{P}=0.025$, Pearson chisquare test, and 73.5 vs $45.2 \%$; $\mathrm{P}=0.001$, Pearson chi-square test, respectively). Multivariate logistic regression showed that the frequency of the $\mathrm{T}$ allele carriers was the only variable with a predictive value for unstable angina, when controlled for the other variables (6.1 (95\% CI $=2.55-14.43)$; $\mathrm{P}<0.001)$. Thus, in a homogenous group of patients, the endothelial constitutive nitric oxide synthase $894 \mathrm{G}>\mathrm{T}$ polymorphism was associated with unstable angina. We suggest that this polymorphism may be a genetic risk factor for unstable angina.
\end{abstract}

\section{Introduction}

The leading mechanism of unstable angina is the transitory interruption of myocardial perfusion by a subocclusive thrombus, superposed on a fissured or eroded coronary atherosclerotic plaque (1). The endothelium
Key words

- Nitric oxide synthase

- Gene

- Polymorphism

- Unstable angina

- Coronary plays a fundamental role in the regulation of the thrombotic process by releasing, among other substances, endothelial-derived relaxing factor (EDRF), synthesized by the endothelial cell (2) and identified as nitric oxide (NO) $(3,4)$. In addition to its vasodilator action (2), EDRF also acts on diverse pro- 
cesses involved in the pathogenesis of atherosclerosis and thrombosis. An inhibitory effect of NO on platelet aggregation and adhesion to the vascular endothelium has been demonstrated (5-7) and EDRF and exogenous NO also cause platelet deaggregation (8). In addition, NO may act on the blood coagulation system through the regulation of the expression of heparin sulfate by endothelial cells (9). Conversely, NO inhibits diverse functions in polymorphonuclear leukocytes, such as chemotaxis and the synthesis and release of superoxide radical $(10,11)$. Furthermore, NO inhibits the adhesion of polymorphonuclear cells to the vascular endothelium (12), thus playing a fundamental role in the control of vascular homeostasis. EDRF is synthesized in the endothelial cell from L-arginine by endothelial constitutive NO synthase (ecNOS), a constitutive enzyme coded by a gene located at locus 7q35-36, containing 26 exons that occupy $21 \mathrm{~kb}$ (13). Some polymorphisms of this gene have been described, as well as their possible association with diverse cardiovascular pathologies. Among these polymorphisms, the $894 \mathrm{G}>\mathrm{T}$ polymorphism has been described in exon 7 of the ecNOS gene, and consists of the substitution of a guanine base by a thymine at nucleotide 894 of the gene; this mutation results in the substitution of the amino acid glutamate by aspartate at the 298th position of the ecNOS protein (Glu298Asp) (14).

The possible association of this polymorphism with coronary heart disease has been studied. In a Japanese population, the frequency of TT homozygotes of this polymorphism was significantly greater in patients with myocardial infarction (MI) than in a control group of healthy people; however, in that study, this mutation was not associated with the degree of severity of coronary atherosclerosis (15). In another Japanese study, a significantly higher frequency of the $\mathrm{T}$ allele was observed in patients with MI when compared with a control group (16). In an
English population, a significantly higher frequency of TT homozygotes was reported in a group of patients with coronary disease and in another group of patients with recent MI when compared with their respective healthy controls (17). With regard to acute coronary syndromes (ACS), a study in a Korean population (18) analyzed the effect of two polymorphisms of the ecNOS gene, the $894 \mathrm{G}>\mathrm{T}$ and the polymorphic variation in intron $4(4 a 4 b)$, on the development of ACS (acute myocardial infarction and unstable angina). In that study, the GG genotype of the ecNOS $894 \mathrm{G}>\mathrm{T}$ polymorphism had an additive beneficial effect on $4 \mathrm{a}$ allele carriers of the ecNOS $4 \mathrm{a} 4 \mathrm{~b}$ polymorphism. In another study conducted on an Italian population (19), the effect of the $894 \mathrm{G}>\mathrm{T}$, $4 \mathrm{a} 4 \mathrm{~b}$ and $-786 \mathrm{~T}>\mathrm{C}$ polymorphisms on the predisposition to ACS was also analyzed. The homozygosity for the ecNOS 4a rare variant represented an independent predisposition factor to ACS. In addition, an increased predisposition to ACS was observed in subjects carrying the -786CC/894TT genotypes.

In a sample from a southern Brazilian population of European ancestry studied by Rios et al. (20), the ecNOS promoter-786T $>C$ but not the ecNOS $894 \mathrm{G}>\mathrm{T}$ polymorphism was associated with coronary artery disease (CAD) (20). Haplotype analysis showed that both haplotypes with a $-786 \mathrm{C}$ allele (i.e., $-766 \mathrm{C} / \mathrm{G}$ and $-786 \mathrm{C} / \mathrm{T}$ ) were predictors for CAD risk, suggesting, as did Tanus-Santos et al. (21), that the promoter variant may be most relevant for the development of CAD in Caucasians. However, a recent meta-analysis (22) indicated the $894 \mathrm{G}>\mathrm{T}$ variant, but not the $-786 \mathrm{~T}>\mathrm{C}$, as a genetic risk factor for CAD. Furthermore, it is not known whether the ecNOS $894 \mathrm{G}>\mathrm{T}$ polymorphism is associated with ACS in our population. Thus, the objective of our study was to identify any possible association of this polymorphism with unstable angina in a southern Brazilian population. 


\section{Patients, Material and Methods}

Written informed consent was obtained from all of the participants and the Ethics Committee of the Hospital de Clínicas de Porto Alegre, Brazil, approved this study.

\section{Study population}

A case-control study was conducted in a southern Brazilian population. Patients submitted to percutaneous revascularization of the culprit lesion between August 2000 and August 2003 were included. A total of 156 unrelated patients (111 men and 45 women) were included in the study according to the following criteria: patients should 1) present symptomatic angina, 2) have an indication for percutaneous revascularization, and 3) sign the informed consent to participate in the study. The study population was mainly of European ancestry, i.e., of Italian, Portuguese and German descent (97.44\%); only 4 patients were of African origin. Patients were divided into two groups: group $1(\mathrm{~N}=83)$, patients with unstable angina according to the Braunwald classification (types I, II, III, $\mathrm{B}$, or $\mathrm{C})(23)$ and group $2(\mathrm{~N}=73)$, patients with stable angina. Asymptomatic patients were not included in the study.

\section{Clinical and demographic data}

The following data were used for clinical evaluation: clinical presentation (stable or unstable angina), age, functional class according to the New York Heart Association (NYHA) classification (24), plasma lipid profile, risk factors for coronary disease such as diabetes mellitus, systemic arterial hypertension (patients taking medication or with a previous diagnosis), smoking (smokers or ex-smokers of 1 or more cigarettes/day for more than 5 years), body mass index, history of previous MI, family history of cardiovascular disease (history of MI or cardiovascular death before 60 years of age in a first degree relative), and medication in use (aspirin, nitrates, angiotensin-converting enzyme inhibitors, statins, calcium channel blockers, B-blockers).

\section{Quantitative coronary angiography}

The following angiographic characteristics of the culprit lesion were evaluated by digital quantitative angiography: type of lesion (noncomplex: types $\mathrm{A}$ and $\mathrm{B} 1$; complex: types $\mathrm{B} 2$ and $\mathrm{C}$, according to the modified American College of Cardiology/American Heart Association classification (25), minimal luminal diameter, reference diameter, degree of stenosis, and lesion length. The diameters were determined using the diameter of the distal portion of the guide catheter as the calibration reference. The lesions were quantified using software for quantitative angiographic analysis with automatic detection of edges (GEMNet CRS V. 5.6.5, Advantage Cardiac Review, General Medical Electric Systems, 1998; Fairfield, CT, USA).

\section{Blood collection and DNA analysis}

A 5-mL blood sample was collected into a sterile system with EDTA as anticoagulant from each patient at admission and stored frozen at $-20^{\circ} \mathrm{C}$ until DNA extraction. Genomic DNA was extracted from leukocytes by a standard method (26). The biallelic 894G $>\mathrm{T}$ polymorphism in exon 7 of the ecNOS gene was identified on the basis of the method of Hibi et al. (15). The polymerase chain reaction (PCR) was performed in a total volume of 50 $\mu \mathrm{L}$ containing about $0.5 \mu \mathrm{g}$ of genomic DNA, 1 U Taq DNA polymerase in Taq buffer (Life Technologies do Brazil Ltda., Invitrogen, São Paulo, SP, Brazil), a final concentration of 0.3 $\mathrm{mM}$ of each dNTP and of $1.5 \mathrm{mM}$ of each primer, ecNOS-F 5'-TCC CTG AGG AGG GCA TGA GGC T-3', and ecNOS-R 5'-TGA GGG TCA CAC AGG TTC CT-3' (Life Technologies do Brazil Ltda., Invitrogen). The re- 
action was carried out in a PTC-100 thermocycler (MJ Research, Inc., Watertown, MA, USA), as follows: an initial denaturation at $94^{\circ} \mathrm{C}$ for $10 \mathrm{~min}$, followed by 30 cycles at $94^{\circ} \mathrm{C}$ for $1 \mathrm{~min}$, at $61^{\circ} \mathrm{C}$ for $1 \mathrm{~min}$, and at $72^{\circ} \mathrm{C}$ for 1 $\mathrm{min}$. The final extension step was prolonged to 10 min. The 457-bp PCR-amplified product $(40 \mu \mathrm{L})$ was cleaved in appropriate buffer with 8-12 U of BanII (GibcoBRL ${ }^{\circledR}$-Life Technologies $^{\mathrm{TM}}$, Rockville, MD, USA) in a total volume of $50 \mu \mathrm{L}$ at $37^{\circ} \mathrm{C}$ for $24 \mathrm{~h}$. The sequence of exon 7 of the ecNOS gene is registered in the EMBL data base as GI: 461317 (GenBank accession number: X76307). The genotype was determined by $2 \%$ agarose gel electrophoretic analysis of the DNA segments. The genotyping was based on the following information: i) GG homozygotes present the guanine base inside the recognition site for BanII; thus, the 457-bp PCR-amplified product is cleaved into two DNA fragments of 137 and $320 \mathrm{bp}$ as a result of digestion; ii) TT homozygotes present the substitution of the guanine base by thymine and therefore only one undigested DNA fragment of $457 \mathrm{bp}$ is visualized on agarose gel; iii) TG heterozygotes are observed on the agarose gel as three DNA fragments of 457, 320, and $137 \mathrm{bp}$. For genotype analysis, a dominant heredity model was assumed (combined TT + TG genotypes versus the GG genotype). Genotyping was performed in a blind fashion, i.e., the investigators were unaware of patient data.

\section{Lipid profile analysis}

A 5-mL blood sample was collected into a sterile system with heparin as anticoagulant from the femoral artery after a 12-h overnight fast before cardiac catheterization. After centrifugation, plasma was stored frozen at $-80^{\circ} \mathrm{C}$ until lipid profile analysis. The plasma concentrations of high-density lipoprotein cholesterol (HDL cholesterol) and total cholesterol were analyzed in the laboratory of the Department of Clinical Pathology, Hospital de Clínicas de Porto Alegre,
Porto Alegre, RS, Brazil, using commercially available systems (HDL-C Plus, second generation, and Cholesterol CHOD-PAP, respectively) and a Roche/Hitachi Automatic Analyzer 917 (Basel, Switzerland).

\section{Statistical analysis}

All the co-variables were coded as 0 for absence of the risk factor and as 1 for its presence; 0 for no use of medication, 1 for the use of medication; 0 for noncomplex lesion type, 1 for complex lesion type; 0 for GG genotype, 1 for combined TT + TG. Data were analyzed using the statistical software package SPSS 12.0 for Windows. The continuous variables are reported as mean \pm SD and the categorical variables as percentage and frequencies. The clinical and angiographic characteristics were compared between groups using the Pearson chi-square test followed by Yates continuity correction for categorical variables, or the Student $t$ test for independent samples for continuous variables.

The chi-square test was applied to determine whether genotype distributions were within Hardy-Weinberg equilibrium. The frequencies of the alleles and genotypes were compared between groups by the Pearson chi-square test. Later, multivariate logistic regression was applied, considering unstable angina as the dependent variable and as covariables those demonstrating $\mathrm{P} \leq 0.20$ in the univariate test and those that can modulate ecNOS, such as age, gender, plasma lipid profile (total cholesterol and HDL cholesterol), smoking habit, and the use of statins. The level of significance was set at 5\% in all analyses.

\section{Results}

\section{Clinical characteristics of the patients}

Table 1 shows the clinical characteristics of the two patient groups (group 1: patients 
with unstable angina; group 2: patients with stable angina). In univariate analysis, the two groups were similar regarding age, gender, body mass index, NYHA functional class, plasma lipid profile, and risk factors for coronary disease such as hypertension, diabetes mellitus, smoking, and a family history of cardiovascular disease. In addition, the two groups were similar regarding the medication in use (aspirin, angiotensinconverting enzyme inhibitors, statins, calcium channel blockers, B-blockers, and nitrates).

\section{Angiographic characteristics}

Table 2 shows the angiographic characteristics of the culprit lesion. The two groups of patients were similar regarding type of lesion, luminal diameter of reference and lesion length, but differed in the minimal luminal diameter $(\mathrm{P}=0.006$, Student $t$-test $)$ and degree of stenosis $(\mathrm{P}=0.005$, Student $t$ test).

\section{Allele and genotype distribution}

The global genotype $(\mathrm{TT}=0.11 ; \mathrm{TG}=$ $0.49 ; \mathrm{GG}=0.40)$ and allele $(\mathrm{T}=0.36 ; \mathrm{G}=$ 0.64 ) frequencies in the sample studied did not differ from the values predicted by the Hardy-Weinberg model $(\mathrm{P}=0.61$, chisquare). The distribution of the alleles and genotypes in patients of each group is compared in Table 3. The frequency of the $T$ allele was significantly higher in patients with unstable angina compared to patients with stable angina (41.6 vs $28.8 \%$; $\mathrm{P}=0.025$, Pearson chi-square test). Also, assuming a dominant heredity model (combined TT + TG genotypes versus GG genotype), the frequency of TT + TG genotypes was significantly higher in patients with unstable angina compared to patients with stable angina (73.5 vs 45.2\%; $\mathrm{P}=0.001$, Pearson chisquare test).

Multivariate logistic regression showed that the presence of the $\mathrm{T}$ allele was the only variable with a predictive value for unstable angina, when controlled for the other variables (previous MI, minimal luminal diam-

Table 1. Clinical, demographic and genetic characteristics of patients with unstable angina (group 1) and patients with stable angina (group 2).

\begin{tabular}{lccc}
\hline Clinical data & $\begin{array}{c}\text { Group 1 } \\
(\mathrm{N}=83)\end{array}$ & $\begin{array}{c}\text { Group 2 } \\
(\mathrm{N}=73)\end{array}$ & $\begin{array}{c}\text { Odds ratio } \\
(95 \% \mathrm{Cl})\end{array}$ \\
\hline Age (years) & $59.90 \pm 10.7$ & $61.90 \pm 10.4$ & \\
BMI (kg/m $\left.{ }^{2}\right)$ & $26.84 \pm 3.99$ & $26.53 \pm 3.27$ & \\
Total cholesterol (mg/dL) & $190.96 \pm 44.83$ & $190.78 \pm 48.95$ & \\
HDL cholesterol (mg/dL) & $38.93 \pm 11.05$ & $39.12 \pm 9.73$ & \\
Male & $61(73.5 \%)$ & $50(68.5 \%)$ & $1.28(0.64-2.56)$ \\
NYHA I-II & $76(92.7 \%)$ & $67(95.7 \%)$ & $0.57(0.14-2.36)$ \\
Hypertension & $50(60.2 \%)$ & $50(68.5 \%)$ & $0.70(0.36-1.35)$ \\
Diabetes mellitus & $20(24.1 \%)$ & $19(26 \%)$ & $0.90(0.44-1.86)$ \\
Smoking & $55(66.3 \%)$ & $45(61.6 \%)$ & $1.22(0.64-2.35)$ \\
Previous MI & $37(45.1 \%)$ & $24(33.3 \%)$ & $1.64(0.85-3.16)$ \\
Family history of CVD & $29(35.4 \%)$ & $31(43.1 \%)$ & $0.72(0.38-1.39)$ \\
Drugs & & & \\
Aspirin & $65(78.3 \%)$ & $53(72.6 \%)$ & $1.36(0.66-2.84)$ \\
ACE inhibitors & $32(38.6 \%)$ & $27(37 \%)$ & $1.07(0.56-2.05)$ \\
Statins & $26(31.3 \%)$ & $23(32.4 \%)$ & $1.05(0.53-2.07)$ \\
Calcium channel blockers & $22(26.5 \%)$ & $14(19.2 \%)$ & $1.52(0.71-3.25)$ \\
B-blockers & $45(54.2 \%)$ & $44(60.3 \%)$ & $0.78(0.41-1.48)$ \\
Nitrates & $52(62.7 \%)$ & $39(53.4 \%)$ & $1.46(0.77-2.77)$ \\
Genotype frequencies & & & \\
$\quad$ GG & $22(26.5 \%)$ & $40(54.8 \%)^{*}$ & $0.30(0.15-0.58)$ \\
TT & $8(9.6 \%)$ & $9(12.3 \%)$ & $0.75(0.27-2.08)$ \\
TG & $53(63.9 \%)$ & $24(32.9 \%)^{*}$ & $3.60(1.85-6.99)$ \\
\hline
\end{tabular}

Data are reported as mean $\pm S D$ or as the number of patients with percent in parentheses. $\mathrm{Cl}=$ confidence interval; $\mathrm{BMI}=$ body mass index; $\mathrm{HDL}=$ high density lipoproteins; NYHA = New York Heart Association functional classification; CVD = cardiovascular disease; $\mathrm{MI}=$ myocardial infarction; $\mathrm{ACE}=$ angiotensin-converting enzyme.

The Student $t$-test was used for comparison of age, BMI, total cholesterol and HDL cholesterol data. The Pearson chi-square test was used for all other data ${ }^{*} \mathrm{P}<0.05$ group I compared to group. All other comparisons were statistically non-significant.

Table 2. Angiographic characteristics of patients with unstable angina (group 1) and patients with stable angina (group 2).

\begin{tabular}{lcc}
\hline Angiographic characteristics & Group 1 $(\mathrm{N}=83)$ & Group 2 $(\mathrm{N}=73)$ \\
\hline Minimal luminal diameter $(\mathrm{mm})$ & $0.68 \pm 0.47$ & $0.89 \pm 0.48^{*}$ \\
Reference luminal diameter $(\mathrm{mm})$ & $2.84 \pm 0.53$ & $2.87 \pm 0.53$ \\
Degree of stenosis $(\%)$ & $76.50 \pm 15.22$ & $69.54 \pm 14.94^{*}$ \\
Lesion length $(\mathrm{mm})$ & $12.40 \pm 5.17$ & $12.93 \pm 4.90$ \\
\hline
\end{tabular}

Data are reported as mean $\pm \mathrm{SD} .{ }^{*} \mathrm{P}<0.05$ (Student $t$-test). 
eter and degree of stenosis of the culprit lesion, age, gender, plasma lipid profile, smoking habit, and the use of statins) (data not shown). The risk of presenting unstable angina for the patients who carried the $\mathrm{T}$ allele was $6.1(95 \% \mathrm{CI}=2.55-14.43) ; \mathrm{P}<$ $0.001)$.

\section{Discussion}

We investigated the possible association between $894 \mathrm{G}>\mathrm{T}$ polymorphism of the ecNOS gene and unstable angina in a Southern Brazilian population mostly of European ancestry (97.44\%). The genotype and allele frequencies of this sample were similar to those reported by Rios et al. (20), who also analyzed subjects of European ancestry from South Brazil, and to those detected for a white Brazilian population (27; data not shown). A significantly higher frequency of the $\mathrm{T}$ allele and of the TT $+\mathrm{TG}$ genotypes was found among patients with unstable angina compared to a group of patients with stable angina (Table 3). Therefore, in the present study, the $\mathrm{T}$ allele was significantly associated with unstable angina. Multivariate logistic regression analysis demonstrated the presence of the T allele (combined TT and TG genotypes) as the only variable with a predictive value for unstable angina, when controlled for the other variables. It should be emphasized that the two groups of patients were similar in terms of clinical char-

Table 3. Allele and genotype distribution of $894 \mathrm{G}>\mathrm{T}$ ecNOS polymorphism in patients with unstable angina (group 1) and patients with stable angina (group 2).

\begin{tabular}{lccc}
\hline $\begin{array}{l}\text { 894G>T ecNOS } \\
\text { polymorphism }\end{array}$ & $\begin{array}{c}\text { Group 1 } \\
(\mathrm{N}=83)\end{array}$ & $\begin{array}{l}\text { Group 2 } \\
(\mathrm{N}=73)\end{array}$ & $\begin{array}{c}\text { Odds ratio } \\
(95 \% \mathrm{Cl})\end{array}$ \\
\hline T allele & $69(41.6 \%)$ & $42(28.8 \%)^{*}$ & $1.76(1.07-2.91)$ \\
G allele & $97(58.4 \%)$ & $104(71.2 \%)$ & $3.36(1.72-6.57)$ \\
TT + TG & $61(73.5 \%)$ & $33(45.2 \%)^{*}$ & \\
GG & $22(26.5 \%)$ & $40(54.8 \%)$ &
\end{tabular}

Data are reported as the number of patients and percent in parentheses. $\mathrm{Cl}=$ confidence interval.

${ }^{*} \mathrm{P}<0.05$ (Pearson chi-square test). acteristics, risk factors for coronary disease and medication in use (Table 1) and that only patients with angina were included in group 2, excluding patients with coronary atherosclerosis but without symptoms. Thus, the fact that the frequency of genotypes was significantly different in a homogenous population in relation to the clinical characteristics suggests an association between the $894 \mathrm{G}>\mathrm{T}$ polymorphism and unstable angina in this group of patients with coronary disease diagnosed by angiography.

EDRF, synthesized from L-arginine by the action of ecNOS, has a fundamental role in the control of vascular homeostasis. Therefore, modifications in the nucleotide sequence of the gene that codes for ecNOS could result in alterations in phenotypic expression, consequently affecting the clinical status of patients with coronary atherosclerosis. In fact, previous studies have demonstrated that this polymorphism is associated with MI in Japanese and English populations (15-17), although the mechanism by which this occurs is unknown. Initial studies have shown that polymorphism of the ecNOS gene may have a functional effect on the enzyme. $\mathrm{T}$ allele carriers without coronary disease were shown to present a vasomotor coronary dysfunction due to an increase in microvascular resistance at rest, that was not seen in $\mathrm{G}$ allele carriers. It seems that this effect might be allele dose dependent, since TT homozygotes present greater dysfunction (28). In another study, also on healthy people, no effect of the $\mathrm{T}$ allele was seen on the vascular response to acetylcholine (ACh), whereas TT homozygotes demonstrated a significantly lower endogenous NO synthesis (29). Also, an attenuated response to ACh was found in coronary patient carriers of the $\mathrm{T}$ allele, showing an endothelial-dependent dysfunction in resistance vessels (30). Cattaruzza et al. (31) demonstrated that there is no difference in the endotheliumdependent NO-mediated relaxant response to $\mathrm{ACh}$ in the saphenous vein segments de- 
rived from patients undergoing aortocoronary bypass with either the TT, TG, or GG genotype. On the other hand, these investigators found that this response was significantly attenuated in segments derived from the CC genotype of the -786T $>$ C polymorphism as compared with CT or TT genotype donors. Also, no apparent differences were observed between the coronary heart disease-positive and -negative patients regarding the $894 \mathrm{G}>\mathrm{T}$ polymorphism (TT 7.6\%, TG 36.9\%, GG $55.6 \%$ vs TT $7.3 \%$, TG $38.4 \%$, GG $54.3 \%$, respectively). Therefore, in this population $894 \mathrm{G}>\mathrm{T}$ polymorphism does not seem to play a major role in the development of coronary heart disease. Moreover, in this regard, the lack of effect of the T-allele on NO-dependent relaxation ex vivo argues against a potential linkage between the $-786 \mathrm{~T}>\mathrm{C}$ and $894 \mathrm{G}>\mathrm{T}$ polymorphism (31). At the molecular level, the $894 \mathrm{G}>\mathrm{T}$ polymorphism has been shown to result in enhanced proteolytic cleavage of the mature ecNOS, suggesting that this polymorphism has a functional effect on the ecNOS protein (32). In a study on cultured human umbilical vein endothelial cells from normal deliveries treated in vitro with or without cigarette smoking extracts, Senthil et al. (33) observed low-ecNOS protein levels and enzyme activities in carriers of the TT genotype, but relatively high mRNA levels in both control and cigarette smoking extract-treated endothelial cells. The reduced ecNOS protein levels and enzyme activities are in agreement with the $\mathrm{T}$ allele being associated with increased vascular risk. The relatively higher ecNOS mRNA could be a compensatory upregulation in transcription, since the mutation at exon 7 could result in accelerated protein degradation (32). Thus, the $894 \mathrm{G}>\mathrm{T}$ polymorphism may indeed affect eNOS protein stability since the TT genotype had a low protein level (33).

In the present study, we used a dominant model pooling TT + TG carriers. It seems that the functional effect of the polymor- phism is present in both homozygous and heterozygous subjects. In fact, in the study by Tesauro et al. (32), a 100-kDa band, product of the proteolytic cleavage of the mature ecNOS, was observed in cell lysates from endothelial cell lines with the TT and TG genotypes, but not with the GG genotype. In another study (34) on patients with autosomal dominant polycystic kidney disease, $\mathrm{Ca}^{2+}$-dependent NOS activity was systematically decreased in renal arteries of patients with the TT genotype or the TG genotype compared to patients with the GG genotype.

Two reports have demonstrated an association of $894 \mathrm{G}>\mathrm{T}$ ecNOS polymorphism with ACS, but only when in combination with other polymorphisms of this gene. In the Korean study (18), the 4a allele for the ecNOS $4 \mathrm{a} 4 \mathrm{~b}$ polymorphism had a protective effect against the development of ACS and the GG genotype for the ecNOS $894 \mathrm{G}>\mathrm{T}$ polymorphism exerted an additive beneficial effect in $4 \mathrm{a}$ allele carriers. In the Italian study (19), an increased predisposition to ACS was observed in subjects carrying the -786CC/894TT genotypes. Some differences between the present study and those cited above should be pointed out. First, in our study the control group consisted of symptomatic patients with stable angina, while in the Korean and Italian studies the control groups were apparently healthy individuals; thus, our population was more homogeneous. Second, we included patients with indication for coronary intervention, i.e., a population differing from those studied in the Korean and Italian investigations, implying a possible selection bias. Third, the Korean and Italian results were obtained in populations of ethnic backgrounds differing from that of our population. All of these aspects may account for the differences between our results and those obtained in the Korean and Italian studies.

The role of the ecNOS gene polymorphisms $(-786 \mathrm{~T}>\mathrm{C}$ in the promoter, the poly- 
morphic variation in intron 4 , and the $894 \mathrm{G}>\mathrm{T}$ variant in exon 7) in the susceptibility to vascular diseases is still controversial. Senthil et al. (33) argued that while there is little doubt that dysfunctional ecNOS is involved in the pathogenesis of vascular diseases, the reasons for the apparently inconsistent findings are: I) false-positive statistical results; II) none of the studied polymorphisms would be functional in regulating ecNOS expression and their associations with vascular diseases are mediated through linkage with other functional ecNOS variant site(s), which may only be polymorphic in some populations but not in others; III) the putative function of these polymorphisms or possibly linked variants at one or more other loci may be conditional on specific environmental factor(s) (33).

To explain such inconsistencies, at least four extensive additional studies would be necessary: i) meta-analyses including studies with a large number of individuals from populations with different clinically relevant phenotypic characteristics and diverse genetic backgrounds; ii) molecular in vitro investigations to identify how functional each eNOS polymorphism could be regarding its capacity to quantitatively or qualitatively modify the ecNOS enzyme; iii) sequencing studies of the ecNOS gene to uncover new candidate mutations explaining putative functional ecNOS enzyme alterations, and iv) genomic analyses to identify additional loci that may modulate the expression of the ecNOS gene.

Since there are few studies demonstrating that the $894 \mathrm{G}>\mathrm{T}$ polymorphism is functional, an alternative explanation for our results is that the association found might be due to linkage disequilibrium with other polymorphisms in the same or other genes, or to interaction with other factors such as smoking habit, physical activity, age, gender, and plasma lipid profile, among others, taking into account that coronary disease is multifactorial. Thus, the probability of a patient to develop unstable angina might depend on all those factors, besides the $894 \mathrm{G}>\mathrm{T}$ polymorphism.

A limitation of our study is the small sample (83 cases and 73 controls). However, since we excluded asymptomatic patients, a fact that permitted us to study a homogeneous population in terms of clinical characteristics (Table 1), and multivariate logistic regression analysis demonstrated the presence of the $\mathrm{T}$ allele as the only variable with a predictive value for unstable angina, when controlled for the other variables, we suggest that the $894 \mathrm{G}>\mathrm{T}$ ecNOS polymorphism is associated with unstable angina in patients from the South of Brazil and that this polymorphism may be considered to be a genetic risk factor for unstable angina.

Studies on other populations are necessary to confirm this hypothesis.

\section{Acknowledgments}

We thank the statistician Vânia Hirakata (Grupo de Pesquisa e Pós-Graduação - Hospital de Clínicas de Porto Alegre, Porto Alegre, RS, Brazil) and Mrs. Daniela Benzano (Grupo de Pesquisa e Pós-Graduação - Hospital de Clínicas de Porto Alegre, Porto Alegre, RS, Brazil) for excellent assistance with the statistical analysis.

\section{References}

1. Worthley SG, Osende JI, Helft G, Badimon JJ, Fuster V. Coronary artery disease: pathogenesis and acute coronary syndromes. Mt Sinai J Med 2001; 68: 167-181.

2. Furchgott RF, Zawadzki JV. The obligatory role of endothelial cells in the relaxation of arterial smooth muscle by acetylcholine. Nature 1980; 288: 373-376.
3. Ignarro LJ, Byrns RE, Buga GM, Wood KS. Endothelium-derived relaxing factor from pulmonary artery and vein possesses pharmacologic and chemical properties identical to those of nitric oxide radical. Circ Res 1987; 61: 866-879.

4. Palmer RM, Ferrige AG, Moncada S. Nitric oxide release accounts for the biological activity of endothelium-derived relaxing factor. 
Nature 1987; 327: 524-526.

5. Azuma $\mathrm{H}$, Ishikawa M, Sekizaki S. Endothelium-dependent inhibition of platelet aggregation. Br J Pharmacol 1986; 88: 411-415.

6. Radomski MW, Palmer RM, Moncada S. Comparative pharmacology of endothelium-derived relaxing factor, nitric oxide and prostacyclin in platelets. Br J Pharmacol 1987; 92: 181-187.

7. Radomski MW, Palmer RM, Moncada S. Endogenous nitric oxide inhibits human platelet adhesion to vascular endothelium. Lancet 1987; 2: 1057-1058.

8. Radomski MW, Palmer RM, Moncada S. The anti-aggregating properties of vascular endothelium: interactions between prostacyclin and nitric oxide. Br J Pharmacol 1987; 92: 639-646.

9. Irokawa M, Nishinaga M, Funayama $H$, Shimada $K$. The effect of endothelium-derived relaxing factor (EDRF) on anticoagulant heparan sulfate on cultured vascular endothelial cell (EC). Circulation 1994; 90: I-396.

10. Moilanen E, Vuorinen $\mathrm{P}$, Kankaanranta H, Metsa-Ketela T, Vapaatalo $\mathrm{H}$. Inhibition by nitric oxide-donors of human polymorphonuclear leucocyte functions. Br J Pharmacol 1993; 109: 852-858.

11. Clancy RM, Leszczynska-Piziak J, Abramson SB. Nitric oxide, an endothelial cell relaxation factor, inhibits neutrophil superoxide anion production via a direct action on the NADPH oxidase. $J$ Clin Invest 1992; 90: 1116-1121.

12. Gaboury J, Woodman RC, Granger DN, Reinhardt P, Kubes P. Nitric oxide prevents leukocyte adherence: role of superoxide. $A m \mathrm{~J}$ Physiol 1993; 265: H862-H867.

13. Marsden PA, Heng HH, Scherer SW, Stewart RJ, Hall AV, Shi XM, et al. Structure and chromosomal localization of the human constitutive endothelial nitric oxide synthase gene. J Biol Chem 1993; 268: 17478-17488.

14. Yoshimura $M$, Yasue $H$, Nakayama $M$, Shimasaki $Y$, Sumida $H$, Sugiyama S, et al. A missense Glu298Asp variant in the endothelial nitric oxide synthase gene is associated with coronary spasm in the Japanese. Hum Genet 1998; 103: 65-69.

15. Hibi K, Ishigami T, Tamura K, Mizushima S, Nyui N, Fujita T, et al. Endothelial nitric oxide synthase gene polymorphism and acute myocardial infarction. Hypertension 1998; 32: 521-526.

16. Shimasaki $Y$, Yasue H, Yoshimura M, Nakayama M, Kugiyama K, Ogawa $\mathrm{H}$, et al. Association of the missense Glu298Asp variant of the endothelial nitric oxide synthase gene with myocardial infarction. J Am Coll Cardiol 1998; 31: 1506-1510.

17. Hingorani AD, Liang CF, Fatibene J, Lyon A, Monteith S, Parsons A, et al. A common variant of the endothelial nitric oxide synthase (Glu298 $\rightarrow$ Asp) is a major risk factor for coronary artery disease in the UK. Circulation 1999; 100: 1515-1520.

18. Park KW, You KH, Oh S, Chae IH, Kim HS, Oh BH, et al. Association of endothelial constitutive nitric oxide synthase gene polymorphism with acute coronary syndrome in Koreans. Heart 2004; 90: 282-285.

19. Fatini C, Sofi F, Sticchi E, Gensini F, Gori AM, Fedi S, et al. Influence of endothelial nitric oxide synthase gene polymorphisms (G894T, 4a4b, T-786C) and hyperhomocysteinemia on the predisposition to acute coronary syndromes. Am Heart J 2004; 147: 516-521.

20. Rios DL, Callegari-Jacques SM, Hutz MH. Endothelial nitric oxide synthase and fractalkine chemokine receptor polymorphisms on angiographically assessed coronary atherosclerosis. Clin Chim Acta 2005; 362: 138-146.

21. Tanus-Santos JE, Desai M, Flockhart DA. Effects of ethnicity on the distribution of clinically relevant endothelial nitric oxide variants. Pharmacogenetics 2001; 11: 719-725.

22. Casas JP, Bautista LE, Humphries SE, Hingorani AD. Endothelial nitric oxide synthase genotype and ischemic heart disease: metaanalysis of 26 studies involving 23028 subjects. Circulation 2004; 109: 1359-1365.

23. Braunwald E. Unstable angina. A classification. Circulation 1989; 80: 410-414.

24. The Criteria Committee of the New York Heart Association. Nomenclature and criteria for diagnosis of diseases of the heart and great vessels. 9th edn. Boston: Little Brown and Co.; 1994. p 253-256.

25. Ellis SG, Vandormael MG, Cowley MJ, DiSciascio G, Deligonul U, Topol EJ, et al. Coronary morphologic and clinical determinants of procedural outcome with angioplasty for multivessel coronary disease. Implications for patient selection. Multivessel Angioplasty Prognosis Study Group. Circulation 1990; 82: 1193-1202.

26. Lahiri KD, Nurnberger JI Jr. A rapid non-enzymatic method for the preparation of HMW DNA from blood for RFLP studies. Nucleic Acids Res 1991; 19: 5444.

27. Marroni AS, Metzger IF, Souza-Costa DC, Nagassaki S, Sandrim VC, Correa RX, et al. Consistent interethnic differences in the distribution of clinically relevant endothelial nitric oxide synthase genetic polymorphisms. Nitric Oxide 2005; 12: 177-182.

28. Naber CK, Baumgart D, Altmann C, Siffert W, Erbel R, Heusch G. eNOS 894T allele and coronary blood flow at rest and during adenosine-induced hyperemia. Am J Physiol Heart Circ Physiol 2001; 281: H1908-H1912.

29. Sofowora G, Dishy V, Xie HG, Imamura H, Nishimi $Y$, Morales CR, et al. In-vivo effects of Glu298Asp endothelial nitric oxide synthase polymorphism. Pharmacogenetics 2001; 11: 809-814.

30. Hambrecht R, Erbs S, Adams V, Linke A, Gielen S, Schuler G. Attenuated endothelium-dependent vasodilation in patients with coronary artery disease: Impact of G894T polymorphism of the endothelial nitric oxide synthase. J Am Coll Cardiol 2001; 37 (Suppl A): 286A.

31. Cattaruzza M, Guzik TJ, Slodowski W, Pelvan A, Becker J, Halle M, et al. Shear stress insensitivity of endothelial nitric oxide synthase expression as a genetic risk factor for coronary heart disease. Circ Res 2004; 95: 841-847.

32. Tesauro M, Thompson WC, Rogliani P, Qi L, Chaudhary PP, Moss $\mathrm{J}$. Intracellular processing of endothelial nitric oxide synthase isoforms associated with differences in severity of cardiopulmonary diseases: cleavage of proteins with aspartate vs. glutamate at position 298. Proc Natl Acad Sci U S A 2000; 97: 2832-2835.

33. Senthil D, Raveendran M, Shen YH, Utama B, Dudley D, Wang J, et al. Genotype-dependent expression of endothelial nitric oxide synthase (eNOS) and its regulatory proteins in cultured endothelial cells. DNA Cell Biol 2005; 24: 218-224.

34. Persu A, Stoenoiu MS, Messiaen T, Davila S, Robino C, El-Khattabi $\mathrm{O}$, et al. Modifier effect of ENOS in autosomal dominant polycystic kidney disease. Hum Mol Genet 2002; 11: 229-241. 